\title{
Utilization Of Midwives As Health Workers of Public Health Center In Implementing The Policy Of Nutrition Improvement Efforts For Balita at Central Buton Regency of Southeast Sulawesi Province
}

\author{
Pendayagunaan Bidan Sebagai Tenaga Kesehatan Di Puskesmas \\ Dalam Pelaksanaan Kebijakan Upaya Perbaikan Gizi Pada Balita \\ Di Kabupaten Buton Tengah Provinsi Sulawesi Tenggara \\ Asfira Sugiarto; Ch. Retnaningsih and Yovita Indrayati \\ email: asfira.sugiarto17@gmail.com \\ Master of Law Science \\ Concentration of Health Law \\ Soegijapranata Catholic University of Semarang
}

\begin{abstract}
To utilize midwives as health workers was essential in rural communities since one of midwife's duties was to carry out the care of balita (children under five). The midwives had direct contact with the balita's mothers, from pre-natal phase to postnatal. They could be utilized to overcome malnutrition problems through the government's policy in accordance with the Article 26 paragraph (2) of the Act Nr. 36 of 2009 on Health Affairs. This study applied socio-legal studies approach using primary and secondary data. The data gathering was conducted by having interviews with some sources and respondents beside having library and related documents studies. This study was analytical-descriptively written. The results showed that the Government of Central Buton Regency had not had a special regulation in relation with utilizing midwives to implement the policy of nutrition improvement efforts. Nevertheless, the government of Central Buton Regency remained using the basic legal products that had been previously issued, namely Local Regulation of Central Buton Regency Nr. 12 of 2016 on Formation and Composition of Regional Devices of Central Buton Regency and Central Buton Regent's Regulation Nr. 38 of 2016 regarding Position, Organizational Structure, Duties and Functions and Administration of Health Office of Central Buton Regency. The health workers at the Wamolo, Rahia and Lakudo Public Health Centers (Puskesmas) experienced several obstacles in implementing nutrition improvement efforts for balitas, namely, among others, lack of budget provided by the local government (APBD), particularly the budget for nutrition, lack of midwives as the human resources and nutrition, inadequate health facilities and the existing roads that remained rocky and hard to travel.
\end{abstract}

Keywords: utilization of midwives, policy implementation, nutrition improvement efforts for balitas. 


\section{PENDAHULUAN}

\section{A. Latar Belakang Masalah}

Keberadaan bidan sebagai tenaga kesehatan sangat esensial di masyarakat pedesaan. Ada beberapa tugas pokok bidan antara lain melaksanakan asuhan kebidanan kepada ibu hamil, melakukan asuhan persalinan fisiologis kepada ibu bersalin, dan menyelenggarakan pelayanan terhadap bayi baru lahir dan balita. Tugas pokok tersebut menggambarkan bahwa bidan memiliki peran penting dalam mendukung upaya kesehatan ibu dan anak serta sebagian besar kelahiran bayi di pedesaan dibantu oleh tenaga kesehatan bidan. Peran bidan yang bersentuhan langsung dengan ibu balita dari fase pra persalinan sampai pasca persalinan, dapat didayagunakan melalui kebijakan pendayagunaan tenaga kesehatan dalam mengatasi masalah gizi buruk. Pendayagunaan tenaga kesehatan bidan ini penting untuk meningkatkan mutu dan pemerataan pelayanan kesehatan dalam rangka menurunkan angka kematian ibu, anak balita, dan meningkatkan kesadaran masyarakat untuk berperilaku hidup sehat.

Undang-Undang Nomor 36 Tahun 2014 tentang Tenaga Kesehatan pada Pasal 22 ayat (1) mengatur bahwa Pendayagunaan tenaga kesehatan dilakukan oleh pemerintah, pemerintah daerah, dan/atau masyarakat sesuai dengan tugas dan fungsi masingmasing berdasarkan ketentuan peraturan perundang-undangan. Undang-Undang tersebut memberikan celah kepada pemerintah daerah atau pencetus kebijakan untuk melahirkan kebijakan strategis melalui pemberdayaan dan sinergitas antar tenaga kesehatan dalam menanggulangi masalah gizi buruk pada balita. Menurut Pasal 141, Pasal 142, dan Pasal 143 Undang-Undang Nomor 36 Tahun 2009 tentang Kesehatan: "Pemerintah sangat diharapkan turut serta berperan aktif dan dituntut untuk meningkatkan perbaikan gizi dimasyarakat, serta memperhatikan keseimbangan dan ketersediaan masalah pangan dan gizi masyarakat".

Peran program pemerintah dapat memberikan distribusi kepada masyarakat akan pentingnya kesadaran dalam upaya peningkatan gizi secara merata dan menyeluruh. Pemerintah berkewajiban menjaga agar mutu gizi dari bahan makanan memenuhi standar mutu gizi yang sesuai. Dalam menjamin tersedianya bahan makanan yang mempunyai nilai gizi yang tinggi secara merata dan terjangkau, pemerintah bertanggungjawab dalam angka kecukupan gizi, standar pelayanan gizi, dan standar tenaga gizi dalam berbagai tingkat pelayanan.

Kabupaten Buton Tengah yang beribukotakan di Labungkari merupakan salah satu kabupaten di Provinsi Sulawesi Tenggara. Berdasarkan data yang ada di Dinas Kesehatan Buton Tengah Tahun 2016 disebutkan bahwa jumlah balita sebanyak 12.478 balita dengan cakupan balita yang ditimbang sebanyak $8.291(66,4 \%)$ balita. Dari penimbangan tersebut balita yang di bawah garis merah (BGM) ditemukan sebanyak 95 balita (1,1\%). ${ }^{1}$ Menurut Profil Kesehatan Indonesia Tahun 2015 bahwa penimbangan balita di Posyandu, ditemukan sebanyak $26.518(0,12 \%)$ balita gizi buruk secara nasional ${ }^{2}$

\footnotetext{
${ }^{1}$ Dinas Kesehatan Provinsi Sulawesi Tenggara, 2016, Buku Profil Kesehatan Provinsi Sulawesi Tenggara Kabupaten/Kota dan Laporan Tahunan Program Gizi Tahun 2016. Kabupaten Buton Tengah : Dinas Kesehatan. hlm. 51.

2 Kementerian Kesehatan Republik Indonesia, 2016, Direktorat Jenderal Kesehatan Masyarakat, Kementerian Kesehatan Republik Indonesia, 2016, Tanggal akses 06 April 2017, diakses http://depkes.go.id/resources/download/pusdatin/profil-kesehatan-indonesia-2016.pdf.
} 
dan kasus gizi buruk pada balita yang ditemukan di Provinsi Sulawesi Tenggara mencapai 245 (0,09\%) balita. Sedangkan tahun 2015 di Kabupaten Buton Tengah jumlah kasus gizi buruk pada balita sebanyak $16(0,16 \%)$ kasus $^{3}$ dan di tahun 2016 sebanyak 26 $(0,21 \%)$ kasus. ${ }^{4}$ Upaya bidan dalam perbaikan gizi buruk pada balita dengan melakukan konseling, penyuluhan rutin, penyebaran leaflet dan pemasangan spanduk yang berhubungan dengan pemenuhan asupan nutrisi. Kegiatan ini dilakukan secara berkala dan terus menerus agar ibu termotivasi untuk memberikan makanan tambahan sesuai dengan kebutuhan dan jadwal pemberian makanan. Mengingat penyebab gizi buruk sangat kompleks, maka diperlukan kerjasama dalam pengelolaan gizi buruk yang komprehensif dari semua pihak. Bukan hanya dari dokter maupun tenaga medis, namun juga pihak orang tua, keluarga, masyarakat serta pemerintah.

Menurut Peraturan Bupati Buton Tengah Nomor 38 Tahun 2016 tentang Kedudukan, Susunan Organisasi, Tugas dan Fungsi Serta Tata Kerja Dinas Kesehatan Kabupaten Buton Tengah pada Pasal 5 ayat (1) Dinas kesehatan merupakan unsur pelaksana urusan pemerintahan yang menjadi kewenangan daerah dan Pasal 6 Dinas Kesehatan mempunyai tugas membantu bupati melaksanakan urusan pemerintahan yang menjadi kewenangan daerah dan tugas pembantuan di bidang kesehatan. Bidang bina gizi, kesehatan ibu dan anak mempunyai tugas pokok membantu Kepala Dinas dalam melaksanakan pembinaan penyelenggaraan program gizi masyarakat, pelayanan kesehatan ibu dan anak balita serta melaksanakan tugas lainnya yang dilimpahkan oleh Kepala Dinas sesuai dengan tugas bidang gizi, kesehatan ibu dan anak balita.

Berdasarkan uraian di atas, maka penulis akan melakukan penelitian tesis dengan judul "Pendayagunaan Bidan Sebagai Tenaga Kesehatan Di Puskesmas Dalam Pelaksanaan Kebijakan Upaya Perbaikan Gizi Pada Balita Di Kabupaten Buton Tengah Provinsi Sulawesi Tenggara".

\section{B. Perumusan Masalah}

Berdasarkan uraian di atas, maka perumusan masalah yang akan diteliti dalam penulisan ini sebagai berikut :

1. Bagaimanakah pengaturan tentang pendayagunaan bidan sebagai tenaga kesehatan di Puskesmas dalam pelaksanaan kebijakan upaya perbaikan gizi pada balita di Kabupaten Buton Tengah Provinsi Sulawesi Tenggara?

2. Bagaimanakah pelaksanaan pendayagunaan bidan sebagai tenaga kesehatan di Puskesmas dalam pelaksanaan kebijakan upaya perbaikan gizi pada balita di Kabupaten Buton Tengah Provinsi Sulawesi Tenggara?

3. Apa saja hambatan dan cara mengatasinya yang dihadapi Pemerintah Daerah Kabupaten Buton Tengah dalam pelaksanaan kebijakan upaya perbaikan gizi pada balita?

\footnotetext{
3 Dinas Kesehatan Provinsi Sulawesi Tenggara, 2015, Profil Kesehatan Provinsi Sulawesi Tenggara Kabupaten/Kota dan Laporan Tahunan Program Gizi Tahun 2015. Tanggal akses 06 April 2017, diakses http://dinkes.sultraprov.go.id/wp-content/uploads/Profile-Dinkes.pdf.

${ }^{4}$ Dinas Kesehatan Provinsi Sulawesi Tenggara, 2016, Loc.Cit, hlm. 25.
} 


\section{Metode Penelitian}

\section{Metode Pendekatan}

Metode pendekatan yang digunakan dalam penelitian ini adalah yuridis sosiologis. Pendekatan sosiologi hukum merupakan pendekatan yang digunakan untuk melihat aspek-aspek hukum dalam interaksi sosial di dalam masyarakat, dan berfungsi sebagai penunjang untuk mengidentifikasi dan mengklarifikasi temuan bahan non hukum bagi keperluan penelitian atau penulisan hukum. ${ }^{5}$ Cara pengumpulan data dilakukan dengan mencari bahan kepustakaan dan berbagai literatur yang selanjutnya dibaca, dipelajari, dan teliti yang merupakan sumber hukum primer ${ }^{6}$, sumber hukum sekunder ${ }^{7}$, dan sumber hukum tersier ${ }^{8}$, seperti buku, peraturan perundang-undangan, artikel, makalah seminar atau lokakarya, dan lain sebagainya.

\section{Spesifikasi Penelitian}

Spesifikasi penelitian yang digunakan adalah penelitian deskriptif analitik, yaitu penelitian yang bertujuan untuk menggambarkan atau mendeskripsikan secara sistematis, faktual dan akurat mengenai fakta dan hubungan antara fenomena yang diteliti yaitu mencari sebab akibat dari suatu hal dan menguraikannya secara konsisten, sistematis dan logis. ${ }^{9}$

\section{Jenis Data}

Jenis data pada penelitian ini adalah jenis data primer dan data sekunder. Penelitian ini mencari dan mengumpulkan data yang diperlukan pada pokok-pokok permasalahan yang ada, sehingga dalam penelitian ini tidak terjadi penyimpangan dalam pembahasan. Penelitian hukum yang bersifat yuridis sosiologis selalu menitikberatkan pada kejadian yang ada dimasyarakat dan mengaitkan pada sumber data. Jenis dan sumber data dalam penelitian ini menggunakan data primer dan data sekunder. Data primer diperoleh langsung dari wawancara kepada narasumber pada Kepala Dinas Kesehatan, Ketua IBI dan pada responden yaitu kepala puskesmas, bidan, gizi dan ibu yang mempunyai balita ${ }^{10}$. Data sekunder terdiri dari peraturan-peraturan, buku-buku, jurnal, hasil-hasil penelitian yang berwujud laporan dan internet. Data sekunder pada penelitian dapat dibedakan menjadi bahan hukum primer, bahan hukum sekunder, dan bahan hukum tersier. ${ }^{11}$

\section{Metode Pengumpulan Data}

Metode pengumpulan data pada penelitian adalah dengan menggunakan data yang disesuaikan pada ruang lingkup penelitian dan tujuan dari penelitian yang akan di teliti.

5 Zainuddin Ali, 2016, Metode Penelitian Hukum, Jakarta : Sinar Grafika, hlm. 105.

${ }^{6}$ Bahan hukum primer merupakan bahan hukum yang bersifat autoritatif artinya mempunyai otoritas. Bahan hukum primer terdiri dari perundang-undangan, catatan-catatan resmi atau risalah dalam pembuatan perundang-undangan dan putusan hakim. Peter Mahmud Marzuki, 2005, Penelitian Hukum, Jakarta : Kencana, hlm 141.

7 Bahan hukum sekunder berupa semua publikasi tentang hukum yang bukan merupakan dokumendokumen resmi. Publikasi tentang hukum meliputi buku teori tentang hukum dan penelitian tesis yang berkaitan dengan penerapan teori hukum, lbid.

${ }^{8}$ Bahan hukum tersier adalah petunjuk atau penjelasan mengenai bahan hukum primer atau bahan hukum sekunder yang berasal dari kamus, ensiklopedia, majalah, surat kabar, dan sebagainya. Ibid.

9 Salim dan Erlies Septiana Nurbani, 2016, Penerapan Teori Hukum Pada Penelitian Tesis Dan Disertasi, Jakarta : Rajawali Pers, hlm. 9.

${ }^{10}$ Burhan Bungin, 2001, Metode Penelitian sosial, Surabaya : Airlangga University Press, hlm 129.

${ }^{11}$ Zainudin Ali, 2016, Loc Cit, hlm.106. 
Teknik pengumpulan data yang digunakan adalah pertama data primer dengan wawancara pada narasumber, kedua data sekunder dengan metode studi kepustakaan yakni data-data yang diperoleh dari buku-buku, karya ilmiah, bahan seminar dan dari peraturan perundang-undangan yang berkaitan dengan permasalahan pada penelitian tentang pendayagunaan bidan sebagai tenaga kesehatan di puskesmas dalam pelaksanaan kebijakan upaya perbaikan gizi pada balita.

\section{Metode Analisis}

Analisis data dalam penelitian ini dilakukan secara kualitatif, yaitu data yang didapat selanjutnya disusun secara sistematis dan analisis secara kualitatif untuk mencapai kejelasan dari rumusan masalah yang dibahas. Setelah analisis data selesai, maka hasil analisis data tersebut akan disajikan dalam bentuk deskriptif. Hasil analisis data tersebut selanjutnya ditarik sebuah kesimpulan yang merupakan dari jawaban permasalahan yang diangkat di penelitian ini.

\section{PEMBAHASAN}

\section{A. Pengaturan Pendayagunaan Bidan Sebagai Tenaga Kesehatan Di Puskesmas Dalam Pelaksanaan Kebijakan Upaya Perbaikan Gizi Pada Balita Di Kabupaten Buton Tengah}

Pemerintah Kabupaten Buton Tengah hingga saat ini belum menerbitkan produk hukum daerah yang mengatur secara khusus tentang pengaturan pendayagunaan bidan di Kabupaten Buton Tengah termasuk pelaksanaan upaya perbaikan gizi pada balita. Namun demikian, dalam pelaksanaan upaya perbaikan gizi tersebut, Pemerintah Kabupaten Buton Tengah tetap mendasarkan pada produk hukum dasar yang telah diterbitkan khususnya mengatur tentang Peraturan Daerah Kabupaten Buton Tengah Nomor 12 Tahun 2016 Tentang Pembentukan Dan Susunan Perangkat Daerah Kabupaten Buton Tengah dan Peraturan Bupati Buton Tengah Nomor 38 Tahun 2016 tentang Kedudukan, Susunan Organisasi, Tugas dan Fungsi serta Tata Kerja Dinas Kesehatan Kabupaten Buton Tengah.

\section{Peraturan Daerah Kabupaten Buton Tengah Nomor 12 Tahun 2016 Tentang Pembentukan Dan Susunan Perangkat Daerah Kabupaten Buton Tengah}

Peraturan daerah merupakan salah satu jenis peraturan perundang-undangan dan merupakan bagian dari sistem hukum nasional yang berdasarkan Pancasila. Pada saat ini peraturan daerah mempunyai kedudukan yang sangat strategis karena diberi landasan konstitusional yang jelas sebagaimana diatur dalam Pasal 18 ayat (6) UndangUndang Dasar Republik Indonesia Tahun 1945. Pasal 2 huruf d angka 2 Peraturan Daerah Kabupaten Buton Tengah Nomor 12 Tahun 2016 dijelaskan "Dinas Kesehatan Tipe A menyelenggarakan urusan pemerintahan bidang kesehatan". Pemerintah daerah menjalankan otonomi seluas-luasnya, kecuali urusan pemerintahan yang oleh undang-undang ditentukan sebagai urusan pemerintah pusat. Pemerintah daerah berhak menetapkan peraturan daerah dan peraturan-peraturan lain untuk melaksanakan otonomi dan tugas pembantuan. Susunan dan tata acara penyelenggaraan pemerintah daerah diatur dalam undang-undang. Menurut UU No. 23 Tahun 2014 Urusan pemerintahan terdapat urusan pemerintahan konkuren. Urusan pemerintahan konkuren ialah urusan pemerintahan yang dibagi antara pemerintah 
pusat dan daerah provinsi dan daerah kota/kabupaten, urusan yang diserahkan kepada daerah menjadi patokan pelaksana otonomi daerah.

\section{Peraturan Bupati Buton Tengah Nomor 38 Tahun 2016 tentang Kedudukan, Susunan Organisasi, Tugas dan Fungsi serta Tata Kerja Dinas Kesehatan Kabupaten Buton Tengah}

Berdasarkan Pasal 6 dijelaskan "Dinas Kesehatan mempunyai tugas membantu Bupati melaksanakan urusan pemerintahan yang menjadi kewenangan daerah dan tugas pembantuan di bidang kesehatan". Pada Pasal 7 dijelaskan dalam melaksanakan tugas sebagaimana dimaksud dalam Pasal 6 butir a, Dinas Kesehatan menyelenggarakan fungsi yaitu perumusan, penetapan dan pelaksanaan kebijakan operasional di bidang kesehatan masyarakat, pencegahan dan pengendalian penyakit, pelayanan kesehatan dan kefarmasian, dan sumber daya kesehatan.

Menurut Undang-Undang Nomor 36 Tahun 2009 tentang Kesehatan Pasal 21 ayat (1) dijelaskan "pemerintah mengatur perencanaan, pengadaan, pendayagunaan, pembinaan, dan pengawasan mutu tenaga kesehatan dalam rangka penyelenggarakan pelayanan kesehatan". Ditegaskan kembali pada Pasal 26 ayat (2) menyebutkan bahwa pemerintah daerah dapat mengadakan dan mendayagunakan tenaga kesehatan sesuai dengan kebutuhan daerahnya. Sebagaimana dimaksud dalam Pasal 26 ayat (1) "Pemerintah mengatur penempatan tenaga kesehatan untuk pemerataan pelayanan kesehatan" dan ayat (2) dijelaskan "pemerintah daerah dapat mengadakan dan mendayagunakan tenaga kesehatan sesuai dengan kebutuhan daerahnya.

Pendayagunaan bidan sebagai tenaga kesehatan menurut asas desentralisasi penyelenggaraan pendayagunaan pemerintah terhadap upaya perbaikan gizi pada balita dilimpahkan atau diserahkan kepada Pemerintahan Kabupaten Buton Tengah sebagai penanggung jawab dalam pelaksanaan kebijakan upaya perbaikan gizi pada balita di wilayah Kabupaten Buton Tengah diatur dalam lampiran pembagian urusan pemerintahan bidang kesehatan di sub urusan upaya kesehatan Undang-Undang Nomor 23 Tahun 2014: 1) Upaya Kesehatan, 2) Sumber Daya Manusia (SDM) Kesehatan, 3) Sediaan Farmasi, Alat Kesehatan, dan Makanan Minuman, 4) Pemberdayaan Masyarakat Bidang Kesehatan. Pemerintah Kabupaten dalam hal ini adalah Dinas Kesehatan yang merupakan unsur pelaksana urusan pemerintahan daerah sesuai dengan Pasal 26 dan Pasal 27 Peraturan Bupati Buton Tengah Nomor 38 Tahun 2016.

Pasal 26 mengatur :

(1) Bidang Kesehatan Masyarakat mempunyai tugas melaksanakan perumusan dan pelaksanaan kebijakan operasional di bidang kesehatan keluarga dan gizi, promosi kesehatan dan pemberdayaan masyarakat, kesehatan lingkungan, kesehatan kerja dan olahraga.

Pasal 27 mengatur:

Dalam melaksanakan tugas sebagaimana dimaksud dala Pasal 26 ayat (1), bidang kesehatan masyarakat menyelenggarakan fungsi:

(1) Penyiapan perumusan kebijakan operasional di bidang kesehatan keluarga dan gizi masyarakat, promosi kesehatan dan pemberdayaan masyarakat, kesehatan lingkungan, kesehatan kerja dan olahraga; 
(2) Penyiapan pembinaan dan pelaksanaan tugas di bidang kesehatan keluarga dan gizi masyarakat, promosi kesehatan dan pemberdayaan masyarakat, kesehatan lingkungan, kesehatan kerja dan olahraga;

(3) Pelaksanaan bimbingan teknis dan supervise di bidang kesehatan keluarga dan gizi masyarakat, promosi kesehatan dan pemberdayaan masyarakat, kesehatan lingkungan, kesehatan kerja dan olah raga.

Sumber dan cara memperoleh wewenang pemerintah berasal dari peraturan perundang-undangan yang diperoleh dengan cara delegatif dan mandat. Istilah hukum delegatif adalah cara penyerahan wewenang dari pejabat yang lebih tinggi, kepada yang lebih rendah. Dalam hal pendayagunaan bidan sebagai tenaga kesehatan sebenarnya merupakan tanggung jawab dari pemerintah pusat. Wewenang Mandat yang didapat melalui atribusi dan delegasi bisa dimandatkan kepada badan atau pegawai bawahan jika pejabat yang memperoleh wewenang itu tidak sanggup untuk melakukan sendiri. HD.Van Wijk menjelaskan arti mandat adalah suatu organ pemerintah mengijinkan kewenangannya dijalankan oleh organ lain atas namanya. ${ }^{12}$

Pemerintah Pusat memberikan wewenang kepada Pemerintah Provinsi yang selanjutnya Pemerintah Provinsi juga melimpahkan kepada Pemerintah Kota/Kabupaten untuk bertanggung jawab dalam melaksanakan pendayagunaan bidan terhadap upaya perbaikan gizi. Pemerintah pusat bertanggung jawab dalam hal menetapkan kebijakan nasional, melakukan pembinaan, pengendalian dan pemantauan terhadap pelaksanaan pendayagunaan bidan terhadap upaya perbaikan gizi. Pemerintah Provinsi mendapatkan delegasi dari Pemerintah Pusat untuk menetapkan kebijakan daerah dan pembinaan dalam pelaksanaan pendayagunaan bidan terhadap upaya perbaikan gizi di Kabupaten Buton Tengah. Pemerintah Kabupaten bertanggung jawab dalam menyelenggarakan pelaksanaan pendayagunaan bidan terhadap upaya perbaikan gizi balita.

Beberapa produk hukum daerah yang terdapat di Kabupaten Buton Tengah yaitu Peraturan Daerah Kabupaten Buton Tengah Nomor 12 Tahun 2016 tentang Pembentukan dan Susunan Perangkat Daerah Kabupaten Buton Tengah dan Peraturan Bupati Buton Tengah Nomor 38 Tahun 2016 tentang Kedudukan, Susunan Organisasi, Tugas Dan Fungsi Serta Tata Kerja Dinas Kesehatan Kabupaten Buton Tengah berkaitan erat dengan Undang-Undang Nomor 36 Tahun 2009 tentang Kesehatan, Undang-Undang Nomor 18 Tahun 2012 tentang Pangan, Undang-Undang Nomor 36 Tahun 2014 tentang Tenaga Kesehatan, Undang-Undang Nomor 23 Tahun 2014 tentang Pemerintah Daerah, dan Peraturan Menteri Kesehatan Nomor 28 Tahun 2017 tentang Izin dan Penyelenggaraan Praktik Bidan. Pada Peraturan Bupati Buton Tengah tidak ada peraturan yang khusus mengatur bidan dalam upaya perbaikan gizi, tetapi ada kebijakan dari pemerintah dinas kesehatan kabupaten buton tengah yaitu semua petugas kesehatan di puskesmas baik itu dari bidan, tenaga gizi ataupun tenaga kesehatan yang lainnya saling melakukan kerjasama dalam upaya penanganan kasus gizi buruk baik itu dalam bentuk penjaringan ataupun pelacakan kasus.

12 Sudrajat Achmad Sodik dan Juniarso Ridwan, 2014, Hukum Administrasi Negara, Bandung : Nuansa Cendekia. hlm.139. 


\section{B. Pelaksanaan Pendayagunaan Bidan Sebagai Tenaga Kesehatan Di Puskesmas Dalam Pelaksanaan Kebijakan Upaya Perbaikan Gizi Pada Balita}

Bidan yang melakukan praktik di fasilitas kesehatan harus memiliki surat izin praktik bidan (SIPB) tercantum dalam ketentuan Permenkes 28 Tahun 2017 Pasal 5 ayat (3). Ketentuan Permenkes 28 Tahun 2017 Pasal 15 ayat (1) tentang perizinan bahwa bidan boleh melakukan praktik atau bekerja di fasilitas pelayanan kesehatan. Ini merupakan aspek legal dalam penelitian ini, bahwa bidan bekerja disalah satu fasilitas pelayanan kesehatan yaitu Puskesmas. Puskesmas merupakan badan hukum yang bertanggung jawab dalam menyelenggarakan pembangunan kesehatan di wilayah kerjanya.

Puskesmas merupakan institusi pelayanan kesehatan yang terorganisir serta sangat dinamis dan berfungsi memberikan pelayanan kesehatan dasar bagi masyarakat. Pada ketentuan Permenkes 28 Tahun 2017 Pasal 2 tentang perizinan menyatakan bidan yang melakukan praktik berpendidikan minimal diploma III kebidanan. Pengawasan bidan dalam menjalankan tugas dan wewenangnya bertujuan untuk meningkatkan mutu pelayanan, keselamatan, dan mengurangi resiko medis. Pengawasan dilakukan oleh Pengurus IBI dan Kepala Dinas Kesehatan Kabupaten Buton Tengah. Monitoring dilakukan dengan berbagai cara yaitu Kepala Puskesmas bekerja sama dengan bidan koordinator KIA (Kesehatan Ibu dan Anak) untuk memantau bidan-bidan lain yang bekerja di desa.

Pembangunan masyarakat yang diselenggarakan oleh puskesmas adalah untuk mendukung tercapainya tujuan pembangunan kesehatan nasional yakni peningkatan kesadaran dan kemampuan hidup sehat seseorang agar terwujud derajat kesehatan yang setinggi-tingginya. Jenis pelayanan kesehatan disesuaikan dengan kemampuan pelayanan puskesmas serta tujuan dari perbaikan gizi masyarakat yaitu untuk meningkatkan kemampuan dan peran serta masyarakat, keluarga dan seluruh anggotanya untuk mewujudkan prilaku gizi yang baik dan benar sesuai dengan pedoman gizi seimbang. Puskesmas dalam melaksanakan kegiatan posyandu atau kegiatan penanganan gizi melibatkan beberapa kader. Kader kesehatan merupakan tenaga yang berasal dari masyarakat yang dipilih oleh masyarakat dan bekerjasama untuk masyarakat secara sukarela. Kader dianggap paling dekat dengan masyarakat dan diharapkan kader dapat melakukan pekerjaannya secara sukarela tanpa menuntut imbalan berupa uang atau materi lainnya. Namun pihak Puskesmas menggunakan dana bantuan operasional kesehatan sebagai insentif kader.

\section{Hambatan Dan Cara Mengatasi Yang Dihadapi Bidan Dalam Pelaksanaan Upaya Perbaikan Gizi Pada Balita}

Hambatan yang dihadapi bidan dalam pelaksanaan upaya perbaikan gizi pada balita yaitu faktor penghambat normatif dan faktor penghambat teknik.

\section{Faktor Penghambat Normatif}

Faktor penghambat normatif yaitu pemerintah kabupaten buton tengah belum memiliki produk hukum yang lengkap terutama peraturan tentang pembuatan rencana pembangunan jangka menengah (RPJM) dan rencana pembangunan jangka panjang (RPJP), kurangnya anggaran pendapatan dan belanja daerah (APBD) utamanya untuk anggaran gizi hanya berkisaran Rp. 10.250.000,00 per triwulan di tahun 2016. Sehingga sasaran pembangunan kesehatan di kabupaten tidak tercapai dengan maksimal. Tentu 
jika produk hukum tersebut belum dibuat maka akan berdampak pada ketertinggalan pembangunan daerah itu sendiri. Karena, peraturan daerah itu merupakan salah satu instrument yang menjadi payung hukum bagi pemerintah dalam melaksanakan fungsi, dan tugas, serta jabatan di bidang pemerintahan. Dalam kaitannya dengan pelayanan administrasi kesehatan dan fungsi tenaga kesehatan tentu tidak akan berjalan dengan baik dan maksimal jika tidak ada payung hukum yang jelas yang mengatur tentang hal yang demikian.

\section{Faktor Penghambat Teknik}

Faktor penghambat teknik adalah kurang tersedianya sumber daya manusia kesehatan. Sebagaimana dimaksud pada Pasal 1 ayat (2) Undang-Undang Nomor 36 Tahun 2009 tentang kesehatan dijelaskan bahwa "Sumber daya di bidang kesehatan adalah segala bentuk dana, tenaga, perbekalan kesehatan, kesediaan farmasi dan alatalat kesehatan serta fasilitas pelayanan kesehatan dan teknologi yang dimanfaatkan untuk menyelenggarakan upaya kesehatan yang dilakukan oleh pemerintah, pemerintah daerah dan/atau masyarakat".

Sumber daya kesehatan adalah semua unsur atau komponen yang digunakan untuk mewujudkan pelayanan kesehatan masyarakat dalam rangka upaya peningkatan derajat kesehatan, yang mencakup; tenaga kesehatan, fasilitas kesehatan, perbekalan kesehatan, dan teknologi dan produk teknologi13. Upaya kesehatan merupakan tatanan yang menghimpun berbagai upaya kesehatan masyarakat dan upaya kesehatan perorangan secara terpadu dan saling mendukung guna menjamin tercapainya derajat kesehatan masyarakat yang setinggi-tingginya ${ }^{14}$.

Berdasarkan hasil penelitian, maka dapat diketahui bahwa kendala-kendala yang dihadapi Pemerintah Kabupaten Buton Tengah dan tenaga kesehatan dalam penanggulangan gizi buruk di Puskesmas Wamolo, Rahia dan Lakudo, antara lain; sampai saat ini belum diterbitkan produk hukum yang mengatur secara khusus tentang pendayagunaan bidan sebagai tenaga kesehatan, kurangnya anggaran pendapatan dan belanja daerah (APBD) utamanya untuk anggaran gizi hanya berkisaran Rp. 10.250.000,00 di tahun 2016 dan dana bantuan operasional kesehatan (BOK) tiap puskesmas, kurangnya sumber daya tenaga kesehatan terutama bidan dan gizi, karena masih ada bidan yang bertugas di dua desa sekaligus serta masih ada puskesmas yang belum memiliki tenaga gizi, dan kondisi jalan yang kurang bagus, karena masih terdapat jalan yang berbatuan dan belum diaspal. Sehingga untuk melakukan kegiatan penanggulangan gizi mengalami hambatan baik dari kegiatan penjaringan ataupun pelacakan gizi buruk pada balita.

\section{Cara mengatasinya}

Ketersediaan fasilitas kesehatan merupakan faktor pendukung yang mempengaruhi pelayanan kesehatan. Pasal 34 Undang-Undang Dasar 1945 menerangkan bahwa "Negara bertanggung jawab atas penyediaan fasilitas pelayanan kesehatan serta fasilitas pelayanan umum yang layak". Berdasarkan hasil penelitian, fasilitas pelayanan kesehatan yang ada adalah Puskesmas, Puskesmas Pembantu, dan Posyandu. Adanya fasilitas tersebut menjadi suatu kemudahan bagi masyarakat untuk memeriksakan

${ }^{13}$ Soekidjo Notoatmodjo, 2010, Etika dan Hukum Kesehatan, Jakarta : Rineka Cipta. hlm.55-60.

14 Wiku Adisasmito, 2010, Sistem Kesehatan, Jakarta : Rajawali Pers, hlm. 74. 
kesehatannya. Puskesmas mempunyai tanggung jawab menyelenggarakan upaya kesehatan perseorangan dan upaya kesehatan masyarakat, yang keduanya apabila dilihat dari system kesehatan Nasional merupakan pelayanan kesehatan tingkat pertama, sesuai dengan Pasal 7 huruf c Peraturan Menteri Kesehatan Nomor 75 Tahun 2014 tentang Pusat Kesehatan Masyarakat bahwa dalam menyelenggarakan kesehatan yang berorientasi pada individu keluarga, kelompok dan masyarakat.

Upaya perbaikan gizi masyarakat ditujukan untuk peningkatan mutu gizi perseorangan dan masyarakat. Peningkatan mutu gizi dilakukan melalui:

1) Perbaikan pola konsumsi makanan yang sesuai dengan gizi seimbang;

2) Perbaikan perilaku sadar gizi, aktivitas fisik, dan kesehatan;

3) Peningkatan akses dan mutu pelayanan gizi yang sesuai dengan kemajuan ilmu dan teknologi; dan

4) Peningkatan system kewaspadaan pangan dan gizi. ${ }^{15}$

Keberhasilan kebijakan dan program ini disamping peran pemerintah juga tidak terlepas dari peran masyarakat dalam mendukung perbaikan gizi buruk pada masyarakat miskin. Sedangkan untuk lintas program Puskesmas selain melibatkan ahli gizi juga melibatkan medis, paramedis, kesehatan lingkungan dan Pusat Kesehatan Masyarakat. Upaya tim penanggulangan gizi buruk Puskesmas Wamolo, Puskesmas Rahia, dan Puskesmas Lakudo untuk mengetahui kejadian dan jumlah balita gizi buruk di wilayah kerjanya, dengan mengadakan penjaringan yaitu dengan jalan menemukan kasus balita gizi buruk melalui pengukuran antropometri dengan mengukur berat badan menurut umur $(\mathrm{BB} / \mathrm{U})$ dan berat badan menurut tinggi badan $(\mathrm{BB} / \mathrm{TB})$ serta melihat tanda-tanda klinis.

Penjaringan ini dilakukan secara pasif dan secara aktif. Penjaringan secara aktif dilakukan dua bulan sekali atau tiga bulan sekali di semua posyandu yang ada di wilayah ketiga puskesmas Kabupaten Buton Tengah. Kegiatan ini dilakukan oleh petugas puskesmas yang dibantu oleh kader kesehatan yang ada di masyarakat. Sedangkan penjaringan secara pasif dilakukan di puskesmas apabila penderita datang ke puskesmas untuk memeriksakan penyakitnya dan saat itu diketahui balita tersebut menderita gizi buruk, juga didapatkan laporan dari kader bahwa ada gizi buruk diwilayah kerja puskesmas.

Berjalannya layanan posyandu harus didukung oleh kader posyandu yang siap berperan serta di dalam layanan kesehatan khususnya pelayanan dasar posyandu. Kader diharapkan dapat menjembatangi antara petugas dengan masyarakat serta membantu masyarakat mengidentifikasi dan menghadapi/menjawab kebutuhan kesehatan masyarakat itu sendiri. Kader dapat membantu mobilisasi sumber daya masyarakat, mengadvokasi serta membantu kebutuhan lokal dimasyarakat.

${ }^{15}$ Soekidjo Notoatmodjo, 2010, Op.Cit, hlm. 81. 


\section{PENUTUP}

\section{A. KESIMPULAN}

Berdasarkan hasil penelitian dan pembahasan diatas, penulis berkesimpulan sebagai berikut:

1. Pemerintah Kabupaten Buton Tengah hingga saat ini belum menerbitkan produk hukum daerah yang mengatur secara khusus tentang pengaturan pendayagunaan bidan di Kabupaten Buton Tengah termasuk pelaksanaan upaya perbaikan gizi pada balita. Namun demikian, dalam pelaksanaan upaya perbaikan gizi tersebut, Pemerintah Kabupaten Buton Tengah tetap mendasarkan pada produk hukum dasar yang telah diterbitkan khususnya mengatur tentang Peraturan Daerah Kabupaten Buton Tengah Nomor 12 Tahun 2016 Tentang Pembentukan Dan Susunan Perangkat Daerah Kabupaten Buton Tengah dan Peraturan Bupati Buton Tengah Nomor 38 Tahun 2016 tentang Kedudukan, Susunan Organisasi, Tugas dan Fungsi serta Tata Kerja Dinas Kesehatan Kabupaten Buton Tengah. Pemerintah Kabupaten dalam hal ini adalah Dinas Kesehatan yang merupakan unsur pelaksana urusan pemerintahan daerah sesuai dengan Peraturan Bupati Buton Tengah Nomor 38 Tahun 2016 pada Pasal 24 ayat (1) dijelaskan "Bidang Sumber Daya Kesehatan terdiri atas: Seksi Pengembangan SDM Kesehatan". Sedangkan Pasal 26 ayat (1) mengatur" Bidang Kesehatan Masyarakat mempunyai tugas melaksanakan perumusan dan pelaksanaan kebijakan operasional di bidang kesehatan keluarga dan gizi, promosi kesehatan dan pemberdayaan masyarakat, kesehatan lingkungan, kesehatan kerja dan olahraga".

2. Pengaturan peran bidan dalam memberikan pelayanan kesehatan kepada anak balita diatur dalam Peraturan Menteri Kesehatan Nomor 28 Tahun 2017 tentang Izin dan Penyelenggaraan Praktik Bidan tercantum pada Pasal 18 dan Pasal 20. Kewenangan bidan dalam pelayanan kesehatan pada anak balita dikategorikan sebagai kewenangan atributif dan kewenangan mandat. Kewenangan atributif bidan dalam pelayanan kesehatan pada anak balita dalam lingkup tugas mandiri tercantum pada Pasal 18 butir (b) Permenkes 28 Tahun 2017 tentang Izin dan Penyelenggaraan Praktik Bidan yang disebutkan bahwa bidan dalam menjalankan praktiknya berwenang untuk memberikan pelayanan kesehatan anak. Selain Pasal 18 butir (b) kewenangan bidan dalam pelayanan kesehatan anak balita berdasarkan lingkup tugas mandiri juga tertuang dalam Pasal 20 ayat (1) (2), (5) dan (6). Sedangkan kewenangan mandat yang diperoleh bidan dalam lingkup tugas pemerintah tercantum dalam Pasal 25 ayat (1) huruf $\mathrm{c}$, dan $\mathrm{f}$. Pendayagunaan bidan sebagai tenaga kesehatan professional adalah sebagai tenaga pelaksana, pengelola, pendidik, dan peneliti.

3. Faktor penghambat normatif pada pemerintah kabupaten buton tengah belum memiliki produk hukum yang belum lengkap terutama peraturan tentang pembuatan rencana pembangunan jangka menengah (RPJM) dan rencana pembangunan jangka panjang (RPJP), kurangnya anggaran pendapatan dan belanja daerah (APBD) utamanya untuk anggaran gizi hanya berkisaran Rp. 10.250.000,00 di tahun 2016. Sehingga sasaran pembangunan kesehatan di kabupaten tidak tercapai dengan maksimal. Jika produk hukum tersebut belum dibuat maka akan berdampak pada ketertinggalan pembangunan daerah itu sendiri. Karena, 
peraturan daerah itu merupakan salah satu instrument yang menjadi payung hukum bagi pemerintah dalam melaksanakan fungsi, dan tugas, serta jabatan di bidang pemerintahan. Untuk sementara Pemerintah Kabupaten Buton Tengah menggunakan produk hukum dari Peraturan Daerah Kabupaten Buton Tengah Nomor 12 Tahun 2016 tentang Pembentukan dan Susunan Perangkat Daerah, serta Peraturan Bupati Buton Tengah Nomor 38 Tahun 2016 tentang Kedudukan, Susunan Organisasi, Tugas dan Fungsi Serta Tata Kerja Dinas Kesehatan Kabupaten Buton Tengah. Sedangkan hambatan teknik yang dialami Pemerintah kabupaten buton tengah yaitu ketersediaan sumber daya kesehatan dan fasilitas kesehatan belum lengkap. Diantaranya adalah kurangnya tenaga kesehatan gizi dan bidan, dimana penyebaran bidan yang belum merata pada setiap desa, sehingga ada bidan yang bertugas di dua desa sekaligus. Sedangkan untuk tenaga gizi tiap puskesmas masih memiliki satu petugas gizi dan masih ada juga puskesmas yang belum memiliki petugas gizi yang dari jurusan gizi itu sendiri.

\section{B. SARAN}

Berdasarkan kesimpulan tersebut di atas maka dapat disarankan sebagai berikut:

1. Ibu balita

a. Agar selalu aktif dalam kegiatan posyandu dan penyuluhan dari tenaga kesehatan terutama pelayanan yang diberikan oleh bidan.

b. Agar selalu mencari informasi atau pengetahuan tentang gizi yang baik pada balita.

c. Anak diberi makanan yang bervariasi, seimbang antara kandungan protein, lemak, vitamin dan mineral.

d. Diharapkan agar tidak tinggal diam jika melihat anak yang mengalami gizi buruk dan sekiranya dapat dilaporkanke Posyandu atau Puskesmas terdekat agar dapat segera ditangani.

\section{Puskesmas}

\section{a. Bagi Puskesmas}

Agar menjaga kualitas dan pelaksanaan upaya perbaikan gizi pada balita dengan melengkapi sarana dan prasarana pelayanan kesehatan dan media untuk penyuluhan atau promosi sehingga dapat meningkatkan motivasi kepada ibu balita untuk mengikuti kegiatan posyandu.

\section{b. Bagi Tenaga Gizi}

1) Agar meningkatkan pengetahuan dengan cara membrowsing tentang pelayanan gizi pada balita dan melakukan pendekatan terhadap masyarakat atau ibu yang mempunyai balita gizi buruk.

2) Harus teliti dalam melakukan pengukuran dan penimbangan pada balita agar mendapatkan hasil yang akurat serta pada saat melakukan pelacakan dan penjaringan melibatkan peran kader masyarakat. 
3) Agar selalu melakukan monitoring dua minggu setelah ditemukan kasus tersebut.

4) Upaya promosi kesehatan yang spesifik terhadap rumah tangga yang memiliki balita dengan status gizi kurang dan status gizi buruk perlu dilakukan sehingga nantinya balita dapat ditangani secara maksimal dan angka morbiditas balita gizi kurang dan gizi buruk dapat ditekan.

\section{c. Bagi Bidan}

1) Agar meningkatkan pengetahuan dengan cara membrowsing atau membaca buku-buku yang berkaitan dengan penanganan upaya perbaikan gizi buruk.

2) Agar selalu melakukan kunjungan rumah pada balita yang terkena gizi buruk dan minta bantuan pada kader yang telah dilatih untuk melakukan pelacakan dan penjaringan

3) Promosi kesehatan masih perlu dilakukan lagi untuk meningkatkan pengetahuan dan kesadaran masyarakat akan pentingnya gizi dan kesehatan balita terutama mengenai ASI ekslusif, Pemberian Makanan Tambahan (PMT) di Posyandu, melakukan survei konsumsi makanan pada keluarga, perilaku sanitasi dan mencuci tangan.

\section{Pemerintah}

\section{a. Bagi Pemerintah Daerah}

1) Agar segera menerbitkan produk hukum tentang pembentukan UPTD Puskesmas, Rencana Pembangunan Jangka Panjang (RPJP), Rencana Pembangunan Jangka Menengah (RPJM) dan Peraturan Dinas Kesehatan tentang pelaksanaan dan pendayagunaan bidan dalam upaya perbaikan gizi pada balita. Jika anggaran tidak mencukupi untuk membuat produk hukum, maka pemerintah daerah kabupaten buton tengah menggunakan acuan peraturan dari Undang-Undang yang lebih tinggi antara lain Undang-Undang Pemerintah Daerah, Undang-Undang Kesehatan dan Undang-Undang Tenaga Kesehatan.

\section{b. Bagi Dinas Kesehatan Kabupaten Buton Tengah}

1) Agar Dinas Kesehatan Kabupaten Buton Tengah melakukan kerjasama dengan Dinas Kesehatan Pemerintah Provinsi atau Dinas Kesehatan Pemerintah Pusat untuk mendapatkan anggaran gizi yang lebih tinggi dalam upaya perbaikan gizi di Kabupaten Buton Tengah.

2) Agar meningkatkan anggaran dana bantuan operasional kesehatan (BOK) tiap Puskesmas

3) Agar meningkatkan monitoring dan evaluasi sehingga pelaksanaan upaya perbaikan gizi sesuai dengan peraturan perundang-undangan dan pedoman tatalaksana gizi.

4) Agar memantau perkembangan pelayanan kesehatan yang dilakukan oleh para petugas kesehatan di wilayah kerja tiap Puskesmas.

5) Agar memberdayakan tenaga bidan dan gizi serta profesi lain dalam melakukan kerjasama pada upaya perbaikan gizi balita. 
6) Agar pemerintah lebih memperhatikan keadaan ekonomi keluarga terutama keluarga yang ekonominya rendah.

\section{c. Bagi IBI (Ikatan Bidan Indonesia Pengurus Cabang Kabupaten Buton Tengah)}

1) Agar sering mengadakan pendampingan dan monitoring serta evaluasi profesi agar pengetahuan/kompetensi bidan meningkat.

2) Harus sering melakukan sosialisasi tentang isi dari ketentuan Peraturan Menteri Kesehatan Nomor 28 Tahun 2017 agar bidan paham akan peraturan yang mengenai profesinya.

3) IBI dan Tim dari Dinas Kesehatan agar selalu melakukan kerjasama dalam upaya kesehatan dan upaya perbaikan gizi dilapangan.

\section{DAFTAR PUSTAKA}

\section{A. Buku}

Adisasmito Wiku, 2010, Sistem Kesehatan, Jakarta : Rajawali Pers.

Ali Zainuddin, 2016, Metode Penelitian Hukum, Jakarta : Sinar Grafika.

Ariani Ayu Putri, Ilmu Gizi, Yogyakarta : Nuha Medika.

Bungin Burhan, 2001, Metode Penelitian sosial, Surabaya : Airlangga University Press.

Dinas Kesehatan Provinsi Sulawesi Tenggara, 2016, Buku Profil Kesehatan Provinsi Sulawesi Tenggara Kabupaten/Kota dan Laporan Tahunan Program Gizi Tahun 2016. Kabupaten Buton Tengah : Dinas Kesehatan.

Hadjon Philipus M., et al, 2001, Pengantar Hukum Administrasi Indonesia, Yogyakarta : Gadjah Mada University Press.

Hapsari Dewi 2014, Waspadai Gizi Buruk Pada Balita, Jakarta Selatan: Tugu Publisher.

Hartono Bambang, 2010, Promosi Kesehatan Di Puskesmas Dan Rumah Sakit, Jakarta: Rineka Cipta.

Ilmar Aminuddin, 2014, Hukum Tata Pemerintahan, Jakarta : Prenadamedia Group.

Koentjoro Diana Halim, 2004, Hukum Administrasi Negara, Bogor : Ghalia Indonesia.

Marbun S.F., 2012, Hukum Administrasi Negara, Yogyakarta : FH UII Press.

Marimbi Hanum, 2010, Tumbuh Kembang, Status Gizi, dan Imunisasi Dasar Pada Balita, Yogyakarta : Nuha Medika.

Marzuki Peter Mahmud, 2005, Penelitian Hukum, Jakarta : Kencana.

Mustafa Bachsan, 2001, Sistem Hukum Administrasi Negara Indonesia, Bandung : PT. Citra Aditya Bakti.

Notoatmodjo Soekidjo, 2007, Kesehatan Masyarakat Ilmu dan Seni, Jakarta : Rineka Cipta.

, 2010, Etika dan Hukum Kesehatan, Jakarta : Rineka Cipta. , 2012, Promosi Kesehatan dan Perilaku Kesehatan, Jakarta : Rineka Cipta. 
Nurbani Erlies Septiana dan Salim, 2016, Penerapan Teori Hukum Pada Penelitian Tesis Dan Disertasi, Jakarta : Rajawali Pers.

Piot Maurice, Rosemary Mc Mahon, dan Elizabeth Barton, 1999, Manajemen Pelayanan Kesehatan Primer, Jakarta : EGC.

Prasetyawati Arsita Eka, 2012, Kesehatan Ibu dan Anak (KIA) dalam Millenium Development Goals (MDGs), Yogyakarta : Nuha Medika.

Profil Kesehatan Kabupaten Buton Tengah, 2016, Buku Profil Dinas Kesehatan Kabupaten Buton Tengah, Kabupaten Buton Tengah. , 2016, Buku Program Tahunan Dinas Kesehatan Kabupaten Buton Tengah, Dinas

Kesehatan Kabupaten Buton Tengah.

Profil Kesehatan Puskesmas Wamolo, 2016, Buku Profil Puskesmas Wamolo, Kabupaten Buton Tengah.

Profil Kesehatan Puskesmas Rahia, 2016, Buku Profil Puskesmas Rahia, Kabupaten Buton Tengah.

Profil Kesehatan Puskesmas Lakudo, 2016, Buku Profil Puskesmas Lakudo, Kabupaten Buton Tengah.

Ridwan HR, 2003, Hukum Administrasi Negara, Yogyakarta : UII Press. , 2008, Hukum Administrasi Negara, Jakarta : Rajawali Pers. , 2009, Hukum Administrasi Di Daerah, Yogyakarta : FH UII Press.

Ridwan, 2009, Tiga Dimensi Hukum Administrasi dan Peradilan Administrasi, Yogyakarta : FH UII Press.

Sudrajat Achmad Sodik dan Juniarso Ridwan, 2014, Hukum Administrasi Negara, Bandung : Nuansa Cendekia.

Sugiyono, 2015, Metode Penelitian Kuantitatif, Kualitatif, dan R\&D, Bandung : Alfabeta.

Walyani Elisabeth Siwi, 2014, Materi Ajar Lengkap Kebidanan Komunitas Teori, Aplikasi, da askeb, Yogyakarta : Pustaka Baru Press.

\section{B. Jurnal dan Internet}

Dian Wahyuni Desimawati, 2013, Hubungan Layanan Keperawatan Dengan Tingkat Kepuasaan Pasien Rawat Inap Di Puskesmas Sumbersari Kabupaten Jember, Universitas Jember, tanggal akses 17 juli 2017, pukul.11.35,diakses,http://repository.unej.ac.id/

bitstream/handle/123456789/3179/Dian\%20Wahyuni\%20Desimawati\%20\%2009231 0101060.PDF? sequence $=1$.

Dinas Kesehatan Provinsi Sulawesi Tenggara, 2015, Profil Kesehatan Provinsi Sulawesi Tenggara Kabupaten/Kota dan Laporan Tahunan Program Gizi Tahun 2015. Tanggal akses 06 April 2017, diakses http://dinkes.sultraprov.go.id/wpcontent/uploads/Profile-Dinkes.pdf.

Direktorat Gizi Masyarakat Direktorat Jenderal Kesehatan Masyarakat, Kementerian Kesehatan RI, 2016, Hasil Pemantauan Status Gizi (PSG) dan Penjelasannya Tahun 2016, Jakarta : Kementerian Kesehatan Republik Indonesia diakses tanggal 27 
Oktober 2017 pukul 22.57 Pm. http://www.kesmas.kemkes.go.id/assets/upload/ dir_519d41d8cd98foo/files/Buku-Saku-Hasil-PSG-2016_842.pdf.

Kementerian Kesehatan Republik Indonesia, 2016, Direktorat Jenderal Kesehatan Masyarakat, Kementerian Kesehatan Republik Indonesia, 2016, Tanggal akses-06April-2017,-diakses http://depkes.go.id/resources/download/pusdatin/profilkesehatan-indonesia-2016.pdf.

\section{Wawancara atau Interview}

Lili Jumiati, Staf Seksi Kesehatan Keluarga dan Gizi Masyarakat Dinas Kesehatan Kabupaten Buton Tengah, Wawancara Tanggal 8 Juli 2017.

Yarni Ibrahim, Ketua Ikatan Bidan Indonesia (IBI) Cabang Kabupaten Buton Tengah, Wawancara Tanggal 10 Juli 2017.

Sunaria, Kepala Puskesmas Wamolo Kabupaten Buton Tengah, Wawancara Tanggal 13 Juli 2017.

Hapsah Imran, Kepala Puskesmas Rahia Kabupaten Buton Tengah, Wawancara Tanggal 4 Juli 2017.

Hadijah, Kepala Puskesmas Lakudo Kabupaten Buton Tengah, Wawancara Tanggal 7 Juli 2017.

Hasil wawancara langsung dengan bidan di Puskesmas Wamolo, Tanggal 11 Juli 2017.

Hasil wawancara langsung dengan bidan di Puskesmas Rahia, Tanggal 5 Juli 2017.

Hasil wawancara langsung dengan bidan di Puskesmas Lakudo, Tanggal 6 Juli 2017.

Hasil wawancara langsung dengan petugas gizi Puskesmas Wamolo, Tanggal 9 Juli 2017.

Hasil wawancara langsung dengan petugas gizi Puskesmas Rahia, Tanggal 5 Juli 2017.

Hasil wawancara langsung dengan petugas gizi Puskesmas Lakudo, Tanggal 7 Juli 2017.

Hasil wawancara langsung dengan orang tua balita di Puskesmas Wamolo, Tanggal 24 Juni-2 Juli 2017.

Hasil wawancara langsung dengan orang tua balita di Puskesmas Rahia, Tanggal 12 Juli 2017.

Hasil wawancara langsung dengan orang tua balita di Puskesmas Lakudo, Tanggal 15 Juli 2017.

\section{Peraturan}

Undang-Undang Dasar Negara Tahun 1945 Pasal $28 \mathrm{H}$ ayat (1), tanggal akses 8 April 2017, diakses di https://luk.staff.ugm.ac.id/atur/UUD1945.pdf.

Undang-Undang Nomor 36 Tahun 2009 tentang Kesehatan, tanggal akses 9 April 2017, diakses di http://sireka.pom.go.id/requirement/UU-36-2009 Kesehatan.pdf. 
Undang-Undang Nomor 18 Tahun 2012 tentang Pangan, tanggal akses 19 April 2017, diakses di https://luk.staff.ugm.ac.id/atur/UU18-2012Pangan.pdf.

Undang-Undang Nomor 23 Tahun 2014 tentang Pemerintahan Daerah, tanggal akses_8_April_2017,diakses_dihttp://www.pnri.go.id/assets/uploads/2016/03/U U-23-2014 PEMERINTAHAN-DAERAH.pdf.

Undang-Undang Nomor 36 Tahun 2014 tentang Tenaga Kesehatan, tanggal akses 8_April_2017,diakses_di_http://gajiroum.kemkes.go.id/gajiroum/data/UU_NO_36 -2014.pdf.

Peraturan Menteri Kesehatan Nomor 23 Tahun 2014 tentang Upaya Perbaikan Gizi, tanggal_akses_8_April_2017,_diakses_di_http://jdih.baliprov.go.id/uploads/pro duk/2014/permenkes-23-2014.pdf.

Peraturan Menteri Kesehatan Nomor 75 Tahun 2014 tentang Pusat Kesehatan Masyarakat, tanggal akses 8 April 2017, diakses di http://www.aidsindonesia.or.id/uploads/ 20141210110659.PMK_No_75_Th_2014_ttg_Puskesmas.pdf.

Peraturan Menteri Kesehatan Nomor 28 Tahun 2017 tentang Izin dan Penyelenggaraan Praktik Bidan, tanggal akses 9 September 2017, diakses di_http://hukor.kemkes.go.id/uploads/ produk_hukum/PMK_No._28_ttg_Izin_dan_Penyelenggaraan_Praktik_Bidan_.p df.

Peraturan Daerah Kabupaten Buton Tengah Nomor 12 Tahun 2016 tentang Pembentukan dan Susunan Perangkat Daerah Kabupaten Buton Tengah.

Peraturan Bupati Buton Tengah Nomor 38 Tahun 2016 tentang Kedudukan, Susunan Organisasi, Tugas dan Fungsi serta Tata Kerja Dinas Kesehatan Kabupaten Buton Tengah. 